\title{
Optimizing Replacement Decisions for Finnish Dairy Herds
}

\author{
By P.J. Rajala-Schultz ${ }^{1,2}$, Y.T. Gröhn ${ }^{3}$ and H.G. Allore ${ }^{3}$
}

\begin{abstract}
${ }^{1}$ Department of Veterinary Preventive Medicine, College of Veterinary Medicine, The Ohio State University, Columbus, OH, USA, ${ }^{2}$ Department of Clinical Veterinary Sciences, Faculty of Veterinary Medicine, University of Helsinki, Finland, and ${ }^{3}$ Section of Epidemiology, Dept. of Population Medicine and Diagnostic Sciences, College of Veterinary Medicine, Cornell University, Ithaca, NY, USA.
\end{abstract}

\begin{abstract}
Rajala-Schultz PJ, Gröhn YT, Allore HG: Optimizing replacement Decisions for Finnish Dairy Herds. Acta vet. scand. 2000, 41, 185-198. - The purposes of the study were to determine how "an optimal herd" would be structured with respect to its calving pattern, average herdlife and calving interval, and to evaluate how sensitive the optimal solution was to changes in input prices, which reflected the situation in Finland in 1998. The study used Finnish input values in an optimization model developed for dairy cow insemination and replacement decisions. The objective of the optimization model was to maximize the expected net present value from present and replacement cows over a given decision horizon. In the optimal solution, the average net revenues per cow were highest in December and lowest in July, due to seasonal milk pricing. Based on the expected net present value of a replacement heifer over the decision horizon, calving in September was optimal. In the optimal solution, an average calving interval was 363 days and average herdlife after first calving was 48.2 months (i.e., approximately 4 complete lactations). However, there was a marked seasonal variation in the length of a calving interval (it being longest in spring and early summer) that can be explained by the goal of having more cows calving in the fall. This, in turn, was due to seasonal milk pricing and higher production in the fall. In the optimal solution, total replacement percentage was 26 , with the highest frequency of voluntary culling occurring at the end of the year. Seasonal patterns in calving and replacement frequencies by calendar month and variation in calving interval length or herdlife did not change meaningfully $(<1 \%-2 \%$ change in the output variables) with changes in calf, carcass or feed prices. When the price of a replacement heifer decreased, average herdlife was shorter and replacement percentage increased. When the price increased, the effect was the opposite.
\end{abstract}

Dynamic programming; replacement; dairy cows; economics.

\section{Introduction}

In recent years the dairy industry has undergone, and is currently undergoing, many changes because of a more competitive business environment. Having joined the European Union, Finnish dairy farmers now face more economic pressures because they must now remain profitable in the more competitive common European market. Fewer farms, larger herds and increasing annual milk production per cow are continuing trends everywhere. Improving farmers' management is critical in today's dairy farming in Finland. Management is a decision making process in which limited resources are allocated to a number of production alternatives (Kay 1981). To maintain profitability, producers must make the best possible 
decisions under uncertain situations on longterm, as well as short-term bases, aiming at the highest possible net revenues.

Various computer-based models have become promising tools; both simulation and optimization models have been developed for decision support in animal breeding and replacement economics (Jalvingh 1992). A basic strategy of these models is to optimize a decision after calculating the expected future net revenue for animals that differ e.g., in age, production capacity and reproductive status.

The purpose of this study was to use one of these existing optimization models ( $\mathrm{McCul}$ lough 1992, McCullough \& DeLorenzo 1996a, b) with Finnish input values to determine how "an optimal herd" with respect to its calving pattern, average herd life, and calving interval would appear under Finnish conditions. Additionally, we evaluated how sensitive these solutions were to changes in input values (mainly price changes) and which factors were most influential in an optimal solution.

\section{Materials and methods}

\section{Dynamic programming model}

Dynamic programming (DP) is a mathematical technique for optimizing a sequence of interrelated decisions that are used to solve optimization problems, i.e. for finding an optimal policy for a multistage problem. A policy is required at each stage. Each stage has a number of states associated with it. The states are the various possible conditions (e.g., a cow being open or pregnant) in which the system could be at that stage of the problem (e.g., 3 months after calving) (Huirne et al. 1997). In most applications, dynamic programming obtains solutions by working backwards, from the end of the problem toward the beginning. It uses a simple, but powerful principal of optimality (often also referred to as Bellman's principal of optimality): Given the current state, an optimal policy for the recurring stages is independent of the policy adopted in the previous stage. The recursions are of the following form: $f_{t}$ (current state) $=$ $\max _{\text {all feasible decisions }}$ (revenues during current stage $+\mathrm{f}_{\mathrm{t}+1}$ (next state) $\}$ (Winston 1994).

In the case of dairy cows, major revenues and costs differ with age, stage of lactation, and production level. Simultaneous consideration of all the variables - biological and economic and their interrelationships is critical for making accurate replacement decisions. If a decision is based on economic considerations, a farmer replaces a cow when a higher profit is to be expected from its replacement (Huirne et al. 1997).

In dairy cattle insemination and replacement problems, the objective function maximizes the expected net present value of present and replacement cows over a given decision horizon. The next state of a cow, however, is not known with certainty. It depends on the current state, the decision made at the current stage, the probability of conception if inseminated, the probability of survival to the next stage, and the probability of transition to a different production level if starting a new lactation. Optimization starts at the end of the decision horizon by setting the value of all cows equal to their carcass value. The non-linear recursive objective function, including the stochastic elements, can be written as

$\mathrm{v}_{1}\left(\mathbf{x}_{1}, \mathrm{~d}_{1}, \ldots, \mathrm{d}_{\mathrm{n}}\right)=\sum_{t=n}^{1} \sum_{x_{t}} \mathrm{p}\left(\mathbf{x}_{\mathrm{t}}\right)\left[\alpha^{\mathrm{t}-1} \mathrm{r}_{\mathrm{t}}\left(\mathbf{x}_{\mathrm{t}} \mathrm{d}_{\mathrm{t}}\right)+\alpha^{\mathrm{n}} \mathrm{r}\left(\mathbf{x}_{\mathrm{n}+1}\right)\right]$,

where $v_{1}=$ the net present value of state $\mathbf{x}$ at stage $t=1$ resulting from series of decisions $d_{1}, \ldots, d_{n}$ where $n$ is the length of a decision horizon; $\mathrm{p}\left(\mathbf{x}_{\mathbf{t}}\right)=$ the probability of being in state $x$ at stage $t$, conditional on being in state $x^{\prime}$ at stage $t-1 ; r_{t}()=$. the return (net revenue) function for being in state $x_{t}$ at stage $t$; and $\alpha$ is the discount factor $1 /(1+i)$, $i$ being the interest rate. 
Possible values of $d_{t}$ are 1) keep and not inseminate, 2) keep and inseminate or 3) replace (DeLorenzo et al. 1992). The time interval between stages is 1 month and thus, stages can be thought to be sequential months.

The DP model used in this study was described by McCullough \& DeLorenzo (1996a, b). They continued the work of Van Arendonk (1985, 1986) and Van Arendonk \& Dijkhuizen (1985), who developed the model for Dutch conditions. In the DP, cows are described by 5 state variables, namely lactation number (parity), days open class (i.e., the month of conception during the breeding period), month of lactation, milk production level, and month of calving. A vector, $\mathbf{x}_{\mathbf{t}}$, of state variable values specifies a single state, such as

$$
\begin{aligned}
& \mathbf{x}_{\mathbf{t}}=\left[\mathrm{i}_{\mathrm{t}}, \mathrm{j}_{\mathrm{t}}, \mathrm{k}_{\mathrm{t}}, \mathrm{l}_{\mathrm{t}}, \mathrm{m}_{\mathrm{t}}\right] \text {, } \\
& \text { where } \mathrm{i}=\text { parity }(\mathrm{i}=1, \ldots ., 12) \\
& \mathrm{j}=\text { conception in month } \mathrm{j} \text { of the } \\
& \text { breeding period }(j=1, \ldots ., 10) \text {, } \\
& \text { when } \mathrm{j}=10 \text {, denotes open (i.e., } \\
& \text { not pregnant) } \\
& \mathrm{k}=\text { month of lactation }(\mathrm{k}=1, \ldots ., 19) \\
& 1=\text { production level }(1=1, \ldots ., 5) \text { and } \\
& \mathrm{m}=\text { month of calving }(\mathrm{m}=1, \ldots ., 12)
\end{aligned}
$$

For all cow states, milk production, feed requirements, gross income, total costs and net revenues are computed. Expected returns are computed over all possible states and each possible state is weighted by its probability $\left(\mathrm{p}\left(\mathbf{x}_{\mathbf{t}}\right)\right)$. The objective is to maximize the expected net present value over a given decision horizon. A time preference was assumed for present over future income and a discounting factor of $0.95 /$ year was used, to account for the change in the value of money over the 5 year decision horizon. The model forces immediate replacement, so that herd size stays constant. No voluntary replacements occur during the first 2 months of lactation. The model also assumes a 60-d waiting period after calving before breeding of the cows begins. All replacements are heifers (whether home-raised or purchased) and enter the herd at calving and have an average production level; a genetic improvement of about $1 \%$ per year was included. Replacement heifers are assumed available whenever a replacement decision occurs.

The length of the decision horizon was initially set to 60 months in this study, based on the results of McCullough \& DeLorenzo (1996a), but the effect on the outputs of varying it was examined by also using 48, 96 and 120 month long decision horizons. Milk production was initially divided into 5 levels, but 3 and 7 production levels were also examined. Refinement of this part of the model into even more production levels was not thought practical, considering the small size of Finnish herds. Van Arendonk \& Dijkhuizen (1985) found that constraining the maximum calving interval to less than 16 months reduced income. Additionally, McCullough \& DeLorenzo (1996a) reported that allowing cows to have up to 19-month calving intervals could be more profitable than replacing them earlier. Thus, 10 days open classes (i.e., allowing 19-month calving interval) were used in this study; however, use of 7 and 8 days open classes was also examined with the base run inputs (see below).

The underlying equations for calculating milk production, feed requirements and discounted expected returns as described in McCullough \& DeLorenzo (1996a), were used in this study; the equations were originally from a model developed in the Netherlands (van Arendonk, 1986). Lactation curves used for computing milk production were estimated from monthly milk yields of 4802 Finnish Ayrshire cows that calved in 1993. The estimation used a $5^{\text {th }}$ degree polynomial (DeLorenzo et al. 1992). These cows were in herds that were randomly picked from herds belonging to the national 
Table 1. Finnish input values used in the base run; prices $^{1}$ reflect the situation in 1998 .

\begin{tabular}{|c|c|}
\hline Inputs & Value \\
\hline Average milk yield, $\mathrm{kg}$ & 7711 \\
\hline Average fat $(\%)$ & 4.3 \\
\hline Average protein $(\%)$ & 3.3 \\
\hline Heat detection rate & 0.7 \\
\hline Conception rate & 0.7 \\
\hline Body weight of a cow, $\mathrm{kg}$, parity 1 & 500 \\
\hline parity 2 & 544 \\
\hline parity $3+$ & 590 \\
\hline Calf mortality, parity 1 & 0.05 \\
\hline parity 2 & 0.02 \\
\hline parity $3+$ & 0.02 \\
\hline Calf birth weight, $\mathrm{kg}$, parity 1 & 36 \\
\hline parity 2 & 38 \\
\hline parity $3+$ & 39 \\
\hline Milk price $^{2}, \mathrm{FIM} / \mathrm{kg}$ (without subsidies) & 1.66 \\
\hline Milk price with subsidies ${ }^{3}, \mathrm{FIM} / \mathrm{kg}$ & 2.16 \\
\hline Fat price, FIM/kg (above $4.3 \%$ ) & 0.0124 \\
\hline Protein price, FIM/kg (above $3.3 \%$ ) & 0.04 \\
\hline Carcass price, FIM/kg (cow) & 10.76 \\
\hline Price of a replacement heifer, FIM & 7000 \\
\hline Average calf price, FIM $/ 60 \mathrm{~kg}$ calf & 600 \\
\hline \multicolumn{2}{|l|}{ Feed cost, FIM $/ \mathrm{kg} / \mathrm{dm}^{4}$} \\
\hline (low/med producers) & 1.23 \\
\hline Feed cost, FIM/kg/dm (high producers) & 1.33 \\
\hline
\end{tabular}

${ }^{1}$ Mälkiä 1999, pers. comm.

${ }^{2}$ Based on $4.3 \%$ fat and $3.3 \%$ protein content, price is from April to June 1998, when the price was lowest (indices for seasonality are given in Table 2.)

${ }^{3}$ Government subsidies vary according to geographical region; a rough overall figure of $0.50 \mathrm{FIM} / 1$ was used in the computations.

${ }^{4}$ Dry matter

dairy herd health recording system and milk registry and that had at least 20 calvings during 1993. These herds were a part of larger population, which has been described previously ( $R a$ jala \& Gröhn, 1998, 1998a). Curves were created for primiparous $(\mathrm{n}=2492)$ and multiparous cows $(n=2310)$ for each month of calving.

\section{Inputs}

Input values used in the base run and prices
Table 2. Seasonal indices for milk pricel and conception rate2 (the base values, indicated with in$\mathrm{dex}=1$, are from Table 1; milk prices include subsidies).

\begin{tabular}{ccc}
\hline Month & Milk price & Conception rate \\
\hline 1 & 1.12 & 1 \\
2 & 1.12 & 0.8 \\
3 & 1.03 & 0.8 \\
4 & 1 & 1 \\
5 & 1 & 1.2 \\
6 & 1 & 1.2 \\
7 & 1.06 & 1.2 \\
8 & 1.15 & 1.2 \\
9 & 1.18 & 1 \\
10 & 1.18 & 1 \\
11 & 1.18 & 1 \\
12 & 1.18 & \\
\hline
\end{tabular}

${ }^{1}$ Mälkiä (1999, pers. comm.)

${ }^{2}$ Taponen (1999, pers. comm.).

(Mälkiä 1999, pers. comm.) reflect Finnish conditions in 1998 and are presented in Table 1. Seasonal variation was incorporated into milk prices, as well as into conception rates (Table 2).

\section{Scenarios}

All the scenarios were run changing only one input value at a time. However, outputs from a "worst case scenario", as well as from a "best case scenario", were also evaluated. In the worst case scenario, all input prices changed so that the changes were economically detrimental and in the best case scenario, the changes were economically beneficial (e.g., lower feed prices, higher carcass price).

\section{Milk price}

The base run used the input values in Tables 1 and 2 with the government subsidies included in the milk price. These subsidies vary according to geographical region within a country (ranging from about 0.3 to 1.0 Finnish Marks 
(FIM)); an overall figure of 0.5 FIM/1 was used in the runs. Another run was performed considering milk price without the subsidies. Seasonality in milk pricing was ignored in one run, using the lowest price throughout the year in the calculations.

\section{Price of a replacement heifer}

Two additional runs were performed assuming the price of a replacement heifer to be higher (9000 FIM) and lower (5000 FIM) than the base price (7000 FIM).

\section{Carcass price and calf price}

When considering carcass value, a $50 \%$ carcass yield was applied (Anon. 1995). The carcass price for a heifer is higher $(13.63 \mathrm{FIM} / \mathrm{kg})$ than that for an older cow $(10.76 \mathrm{FIM} / \mathrm{kg})$. In the base run, the lower price of a cow was used, and a second run used the higher heifer price.

In Finland calves are usually sold at about 60 $\mathrm{kg}$; when calves are sold to market, bull calves are more valuable than heifer calves. The model contributes the income from a calf to a cow during the first month of lactation as a price per kilogram of body weight, assuming the calf was sold during the first week of life. Therefore, only $2 / 3$ of a price of a $60-\mathrm{kg}$ calf was attributed to a cow (assuming a weight of $40 \mathrm{~kg}$ at the time of sale) when calculating the expected net present value of a cow. An average value (between the value of a heifer and a bull calf) was used in the base run. Two other runs used the highest price for a bull calf (800 FIM/60-kg bull calf) and the lowest price for a heifer calf (350 FIM/60-kg heifer calf).

\section{Feed price}

The effects of a $10 \%$ increase and decrease in feed price were examined. This model did not allow for seasonal variation in feed prices. Most cows in Finland are on pasture during the summer months and thus feed prices could be con- sidered lower at that time. Feed intake per cow is largely affected by milk yield, especially at higher production levels. As an indirect way of accounting for lower feed prices during the summer, seasonality in milk price was adjusted to seasonality of milk price minus feed price, and thus milk price from June to August was adjusted upwards in 2 additional runs.

\section{Heat detection and conception rate}

Pregnancy rate (PR) was modeled as a function of heat detection (HD) and conception rate $\left(\mathrm{CR} ; \mathrm{PR}=\mathrm{HD}{ }^{*} \mathrm{CR}\right)$. The base run used heat detection and conception rates of 0.7 , resulting in a PR of approximately 0.5 , in agreement with Jukola et al. (1996). Seasonal variation in conception rate was based on one year's estimates from Finland (Taponen 1999, pers. comm., Table 2). The effects of variation in the fertility parameters on the optimal solution and breeding recommendations will be studied and discussed in Rajala-Schultz et al. (2000).

\section{Results \\ Model specifications}

Annual means of different output values (percentage of cows replaced, average net revenues, average calving interval, average time to disposal, average herdlife, $\%$ of decisions to cull) were examined from the optimal solution for each scenario. The base run used a 60 -month decision horizon, 5 production levels and 10 days open classes. Changing the decision horizon to 96 or 120 months did not meaningfully change any of the output values; the average herdlife was approximately a month shorter with a longer decision horizon (herdlife refers to the length of a cow's life in months from her first calving onward). A 48-month long decision horizon resulted in practically identical output as in the base run.

Using only 3 instead of 5 production levels predicted a slightly longer herdlife and fewer deci- 


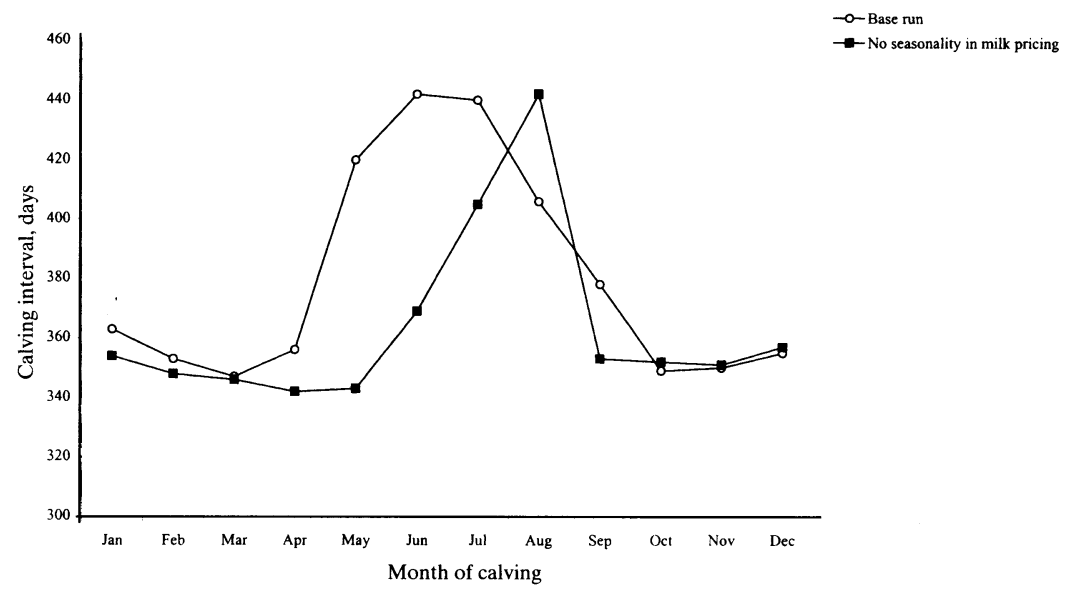

Figure 1. The length of calving interval (in days) by month of calving as a result from optimal insemination and replacement decisions over the decision horizon in the base run and in the run where seasonality in milk price was ignored.

sions to cull, and the net revenues were slightly lower with 3 production levels. With 7 production levels net revenues were also marginally lower, and herdlife slightly shorter. None of the changes was meaningfully different (e.g., herdlife was 0.5 months shorter with 7 production levels).

Using 7 and 8 days open classes (and therefore allowing only a maximum 16 or 17 month calving interval, respectively) shortened average herdlife and length of an average calving interval, and there were fewer decisions to cull and not to breed, as expected. In addition, net revenues were lower when the calving interval was restricted to be a maximum of 17 months than when it could to be up to 19 months.

Thus, all subsequent runs used a 60 -month decision horizon, 5 milk production levels and 10 days open classes.

\section{"Optimal herd" in the base situation}

The most influential factor in optimal solutions for replacement and breeding decisions on dairy farms in Finland was seasonality in milk pricing. Milk price is highest from September to December and lowest from April to June. Also, conception rate (and thus pregnancy rate, which was the product of heat detection and conception rate) varied according to season. The probability of conceiving was highest from June to September and lowest in February and March.

In the optimal solution, weighted expected net revenues per cow were highest in December, and reached their minimum in July. Regarding the expected net present value of a cash flow from a replacement heifer over the 60 -month decision horizon, the optimal time of her calving was September. This remained true in all scenarios in which prices varied. When milk price was constant, the optimal time of having a heifer calve was December. Across all scenarios, the least profitable time to bring a heifer into a herd was May.

In the optimal solution, the average calving interval was 363 days, with considerable seasonal variation (Fig. 1). On average $8.1 \%$ of the calving intervals were longer than 13 months. 


\section{A. Base run}

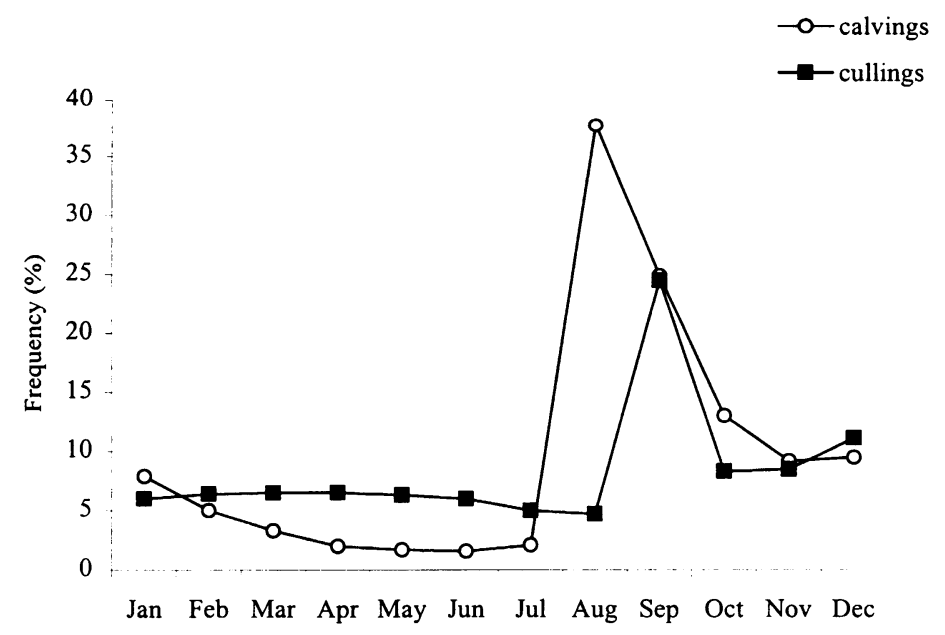

B. No seasonality in milk pricing

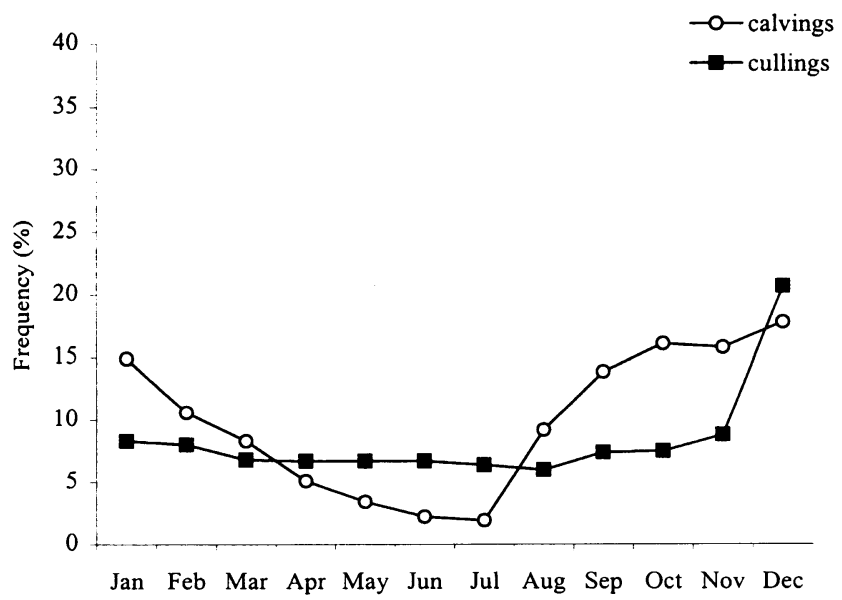

Figure 2. The frequency of calvings and replacements (as a percentage from the annual total) by calendar month on the base run and when seasonality in milk price was ignored.

Practically all $(99.3 \%)$ cows calving in June had a calving interval of at least 14 months, $78.8 \%$ of the cows calving in May and $51 \%$ of the cows calving in April also had longer than a 13-month calving interval.
In the optimal solution, most $(75.8 \%)$ of the calvings occurred in the fall, during August through October, and only $7.3 \%$ of the cows calved in spring and summer (April-July) (Fig. 2A). Replacement percentage in the optimal so- 


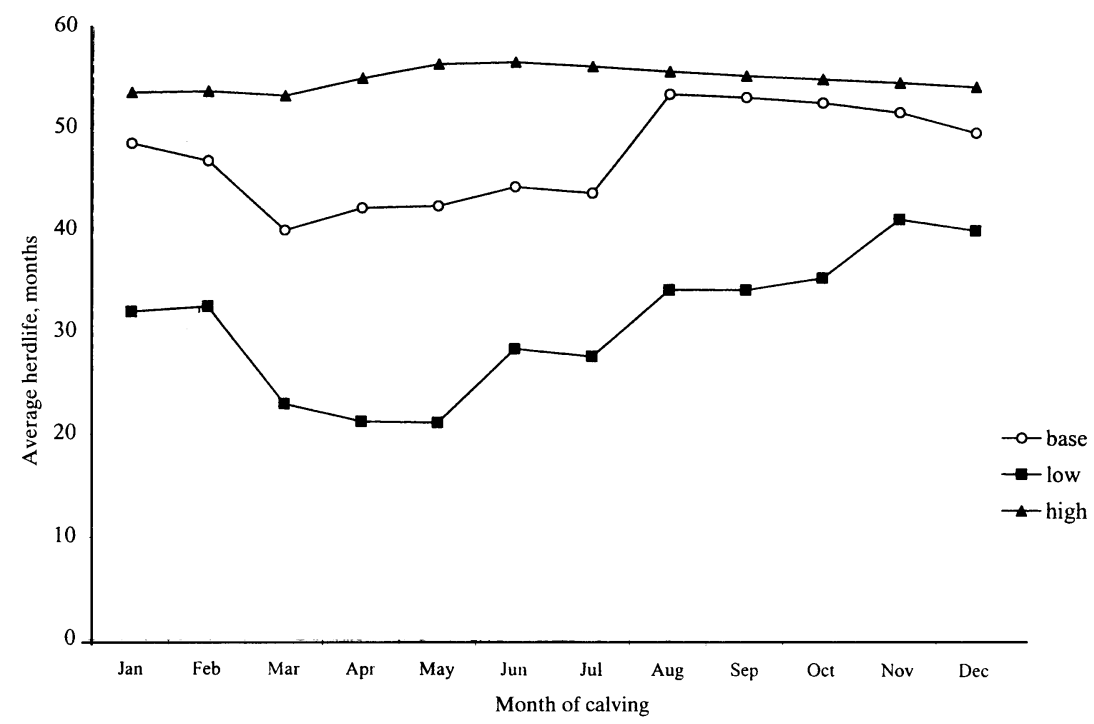

Figure 3. The average herdlife (in months from the first calving) by month of calving with different replacement heifer prices: low $=5000$ FIM; base $=7000$ FIM; high $=9000$ FIM.

lution was 26. The frequency of replacements by calendar month is presented in Fig. 2A. The mode of the distribution occurred in September, with almost $25 \%$ of replacements occurring then, followed by $11 \%$ occurring in December. None of the culling occurring in the first part of a year (January through August) was voluntary. The highest proportion of voluntary culling occurred among cows that calved in spring and summer (March through July). Voluntary replacement of cows occurred, on average, 178 days after calving. This varied from 161 to 259 days, depending on parity.

The optimal average herdlife was 48.2 months and showed a seasonal pattern (Fig. 3). Cows calving from August to December stayed in a herd longest and cows calving in the spring (March - May) tended to have the shortest herdlife. The average herdlife for cows calving in March was 13.2 months shorter than for cows calving in August.

\section{Sensitivity analysis}

When seasonality in milk pricing was ignored, much of the patterns in optimal calving and culling distributions observed in the base run changed. There was not such a marked peak in calving and replacement frequencies in late summer; however, most calvings still occurred during the fall and at the end of the year (Fig. 2 B). With a fixed price for milk, average herdlife was 50.6 months and it varied between 48.8 and 52.8 , with the exception of July (42.6 months). The longest calving intervals (mean 442 days) were observed among cows that calved in August (Fig. 1).

Net revenues per cow per year, naturally, were affected when the analysis was performed without government subsidies in milk price. Overall, replacement percentage was slightly lower with lower milk prices ( 25 versus 26 in the base run). Otherwise, for the scenario with the lower milk price, resultant optimal calving and re- 
placement distributions remained quite similar as compared, by inspection, to the optimal solution from the base run. Changes in replacement heifer, calf, and carcass prices did not considerably change the expected net revenues (changed ENR by $<1 \%$ ) over the 60 -month decision horizon. A $10 \%$ increase in feed prices resulted in approximately an $8 \%$ decrease in the average net revenues over the decision horizon and the change was approximately as large in the opposite direction with $10 \%$ decrease in feed price.

The optimal solution with respect to average herdlife, calving interval, and calving and replacement frequencies by calendar month was not meaningfully affected by the changes in calf or feed prices (e.g., a change in the length of an average herdlife was less than half a month and in the length of a calving interval 1-2 days). However, a change in carcass price had somewhat more impact on the optimal solution: With a higher carcass price, total replacement percentage was 28 (versus 26 in the base run) and the percentage of decisions to cull during the decision horizon increased from $8.2 \%$ to $11.1 \%$.

On the other hand, changes in the replacement heifer price had a greater effect on several components of the solution. When the price decreased to 5000 FIM, total replacement percentage increased from 26 to 37 and average herdlife decreased from 48.2 months to 33.5 months. At the same time, the marginal rate of voluntary culling increased from $3.9 \%$ to $12.1 \%$ and also the percentage of decisions to cull increased from 8.2 to 18.7 . When the replacement heifer price increased, total replacement percentage decreased to 23 and herdlife increased to 54.3 months. The proportion of culling that was voluntary became smaller as the price of a heifer increased, and the percentage of decisions to cull decreased from $8.2 \%$ to $4.0 \%$. Average herdlife by month of calving for differing replacement heifer prices is presented in Fig. 3. The seasonal patterns of calving and replacement distributions were the same as in the base run despite the different price changes. When seasonality in feed prices was indirectly accounted for by adjusting milk prices to a higher level for summer months, changes in the optimal solution were minor. As the milk prices were adjusted upwards, the average calving interval shortened (only by a couple of days, however) and the variation was less. When milk prices from June to August were adjusted to a level of the highest time of the year, the calving and replacement distributions still followed the same pattern as in the base run.

\section{Best and worst case scenarios}

When all input prices were simultaneously changed so that the changes were economically beneficial to a farmer (lower feed prices, higher carcass price, lower replacement heifer price etc.), total replacement percentage was higher (47\%) and marginal rate of voluntary culling was $18.3 \%$. In addition, average herdlife was considerably shorter (26.2 months). Net revenues were, as expected, higher than in the base run, because feed costs were lower and carcass price was higher. In the worst case scenario, with unsubsidized milk prices and higher feed costs, net revenues were lower. Total replacement percentage was lower (23\%) and average herdlife longer (54.8 months). However, in both cases, calvings concentrated in August and September and September remained the most profitable time to have a replacement heifer calf.

\section{Discussion}

All the underlying equations for calculating feed requirements and expected future milk production and net revenues used in this study were adopted from McCullough \& DeLorenzo (1996a, b), whose work was based on a model 
developed in the Netherlands (van Arendonk, 1985, 1986). Lactation curves on which the milk production calculations were based were estimated using Finnish data. The adjustment factors for the effect of stage of lactation and gestation stage for milk, milk fat and protein were based on United States Department of Agriculture adjustment factors because such factors were not available for Finnish conditions. The lack of Finnish adjustment factors in the calculations is assumed to have a negligible effect on the results (e.g., optimal calving and replacement patterns), because the results are based on relative production levels and relative ranking of the cows. Furthermore, the same set of adjustment factors was used for all cows and their milk production and net revenues were calculated in the same manner.

Milk pricing did not take into account protein yields. Thus, if there were large differences in milk protein yields, they were not captured in the calculations. However, there are not large variations in milk protein within breed, so including protein in the analysis is unlikely to affect the results meaningfully. In Finland, milk pricing is also based on somatic cell count and bacteria count, but neither of these was accounted for in the model. Effects of diseases, such as mastitis, ketosis and milk fever, and their effect on milk production (and milk quality) and resultant economic returns, will be addressed in further research. Only the effects of clinical mastitis have been included in a DP model (Houben et al. 1994); however, other diseases are also economically important, yet no suitable model exists accounting for them.

In Finland, the price of milk paid to farmers is partly government subsidized; these subsidies vary according to geographical region of the country. The base run used an overall figure of $0.50 \mathrm{FIM}$ as the subsidy added to the base milk price. Net revenues, of course, were considerably affected when the analysis was performed without including the subsidies in the milk price. Without the government subsidies in milk price, the model predicted production to be unprofitable for part of a year (in spring when the milk prices were lowest, reflecting the 1998 situation).

This model only accounted for yield-related costs, such as feed costs (but not for any other variable costs, such as interest and principal payments on any investments on buildings or equipment); hence, the expected returns are valid under partial budgeting.

This model maximized the expected net revenues per cow per year. However, under a milk quota system, which exists in Finland, this might not be the best approach; it might be more appropriate to maximize the gross margin per kilogram of milk rather than per cow (Kristensen \& Thysen 1991, Jalvingh et al. 1994). Kristensen \& Thysen (1991) reported that culling should be less intensive under a quota system and that reduction of costs are the most important means for improving herd net returns. They considered housing capacity to be the major limitation without a quota, but that under a (sufficiently low) quota housing would not be limiting. Thus, the efficiency of an individual animal is not necessarily equal to herd efficiency as the number of animals is not fixed, but could increase. However, Jalvingh et al. (1994) used linear programming and dynamic probabilistic simulation to determine the optimal calving pattern in the Dutch situation, restricting the annual herd production. They concluded that it would be more profitable to produce the quota with fewer animals. Additionally, Houben (1995) studied the effect of milk quotas on optimal dairy cow insemination and replacement decisions. This study also determined the effect of including opportunity costs of labor and buildings on the optimal strategies. The results suggested that if opportunity costs of labor, housing and non-yield re- 
lated costs were included, then the optimal insemination and breeding decisions to maximize the expected net returns per cow were the same as those to maximize the expected net returns per $\mathrm{kg}$ of milk.

In the optimal solution in this study, most of the calvings occurred in the fall. Similarly, Jalvingh et al. (1993) found that under Dutch conditions it was most profitable to have calvings concentrate in the autumn. Under Finnish conditions, this was primarily driven by the seasonality in milk pricing, prices being highest from September to December. This is due to temporary shortage of milk during late fall and early winter; dairy plants have price incentives to motivate farmers to have more cows calving in the fall. However, if all cows calved during the fall, this would affect the supply and demand relationship and thus the price of milk.

No seasonality was incorporated into any other prices except for milk price. We recognize that carcass and heifer prices in Finland can vary according to demand and supply, but there is no defined, seasonal pattern (Mälkiä 1999, pers. comm.). It is likely that if most cows were culled during the fall, the supply of meat could temporarily exceed demand and, in turn, depress carcass price. The current model did not allow for incorporating seasonal changes into feed prices. However, most cows are on pasture during the summer in Finland, and feed prices could be expected to be lower. Therefore, we indirectly tested possible effects by increasing the milk prices during the summer months. Calvings and replacements were distributed slightly more evenly than in the base run, but still were concentrated in the fall. The concentration of calvings in the fall is, in addition to the seasonal milk pricing, also partly driven by the fact that cows calving in the fall produce, on average, significantly more than cows calving during spring or summer (Rajala \& Gröhn 1998b).

Total replacement percentage in the optimal so- lution was 26 , which is lower than what has been observed in the field data from Finland (i.e., 31.6; Rajala-Schultz \& Gröhn 1999). The average herdlife in the base scenario was 48.2 months, indicating that it is profitable to keep cows longer in the herd than is done currently in Finland; on average cows stay in a herd for approximately 2-3 lactations (Anon. 1997). However, the DP used in this study did not directly take into account occurrence of any diseases or their effects on production, fertility, or survival and thus, on net revenues from cows. Since somatic cell count has been introduced as one component of milk pricing in Finland, farmers have been culling vigorously to improve udder health and to meet milk quality standards. This could be a possible reason for the observed difference between the field data and the results from this optimization model. Some of the difference could also be explained by possible fluctuation in meat prices, based on supply and demand, which was not accounted for in the model. Also, as mentioned, the current model did not allow restricting production for a herd (thus accounting for a quota system, which exists in Finland). In some cases, it might be more profitable for a farmer to sell a cow than to keep milking her, if his/her quota has already been met for a year, or if carcass price was high at that point. In fact, our observation of a higher replacement rate with higher carcass price would support this.

A seasonal pattern was observed in the length of average herdlife, it being between 51.7 and 53.4 months for cows calving in August and September and 40.0 and 42.2 months in March and April. Van Arendonk (1985) reported an average herdlife of 42.9 months under Dutch conditions and McCullough \& DeLorenzo (1996b) reported an average herdlife of 32 months under Florida conditions, which are both shorter than in Finland. The replacement costs are quite high in Finland, which could explain 
the difference. In fact, when the price of a replacement heifer was 5000 FIM (instead of 7000 FIM in the base run), the average herdlife was 33 months.

The calving interval resulting from the optimal policy over the decision horizon was 363 days in the base run, which is slightly shorter than what has been observed (i.e., 389 days) in Finnish field data from 1993 (Rajala \& Gröhn 1998a). The seasonal variation observed in the length of a calving interval by month of calving could be explained by the goal of having cows calving during the fall. Most of the cows calving in spring and early summer had longer than 13 month calving intervals; in fact the average calving interval for cows calving in June was 439 days. It was optimal not to start breeding them immediately so that they calve in the fall and their peak production is coincident with the highest milk prices.

In the sensitivity analysis, changes in the replacement heifer price had the greatest effect on the optimal solution, besides the seasonal effect of milk pricing. At each stage and each decision the expected future net revenues from a cow currently in a herd are compared to those of a replacement heifer and if the value of a new heifer is higher, the cow should be replaced. The number of decisions to cull was lower when replacement heifer prices were higher than the base price. With a low heifer price, the number of decisions to replace over the decision horizon was considerably higher. It was clearly more profitable to keep the cows longer when the replacement costs were high. The length of herdlife did not have a distinct seasonal pattern with higher heifer price; all cows were kept longer, independent of the timing of their calvings. Most of the calvings and replacements still occurred during the fall, because of the seasonal milk pricing and differences in production level by season of calving. The model forced immediate replacement. In
Finland, where most heifers are home-raised, this might not always be applicable. Hence, it might not be possible to follow the optimized recommendations. If there was a shortage of heifers, e.g., in a fall, it could be expected that heifer prices would go up. Consequences of this would be similar to what we observed in the sensitivity analysis with a higher replacement heifer price: it would be more profitable to keep cows longer. In fact, if heifer price was higher between September and December, herdlife was slightly longer, but calving and replacement distributions were still very similar to the solution in the base run.

The average milk yield used in the study was slightly higher than the average yield in Finland in 1998. It was an estimate based on 1997 yield, because at the time of the analysis, 1998 average production was not yet available. Also, body weights of cows by parities were estimated, because detailed information was not available. Estimates for cows in parity 1 might have been inflated. Additional runs, however, were performed with a lower average milk yield and lower body weights, but these changes did not cause meaningful changes in the optimal solution. Our estimate for annual genetic improvement might have been lower than observed (Anon. 1999), but this is unlikely to affect the results meaningfully; Van Arendonk (1985) reported that the rate of genetic improvement did not greatly affect the optimum replacement policy.

It is important to keep in mind that one motivation for developing this kind of optimization model has been to support decision-making processes on an individual herd level. However, it is clear that computer models are always a simplification of reality. Situations can be very different across herds and a set of replacement recommendations that are optimal under a certain scenario might not be optimal in a different situation. This research used "average national 
values" to study the optimal calving patterns and replacement policies under Finnish conditions. However, the optimal solution found in this study might not be optimal in each individual herd in Finland, as conditions (e.g., milk production level, reproductive performance, feed prices) vary across herds. Our results showed that changing one input at a time did not meaningfully change the optimal policy and replacement patterns, except if the seasonality in milk pricing was ignored. Also, even if several prices varied simultaneously, but milk pricing remained seasonal, it was optimal to have calvings concentrated in the fall. McCullough \& DeLorenzo (1996b) showed that, with the exception of pregnancy rate, varying inputs individually rarely caused meaningful changes in optimal policy. McCullough \& DeLorenzo (1996b) reported, however, that varying several inputs simultaneously resulted in meaningful changes in optimal policies and in addition, interactions in price and management levels were important. The effects of different conception and pregnancy rates on optimal policies under Finnish conditions will be evaluated in further research (Rajala-Schultz et al. 2000).

\section{Acknowledgments}

This study was supported by the Finnish Academy (Helsinki, Finland). The authors acknowledge the help of Pirjo Mälkiä at the Association of Rural Advisory Centres, Helsinki and Juhari Tagonen at University of Helsinki, Finland for providing the information on Finnish input values. Michael DeLorenzo's assistance in applying the dynamic programming model used in the study and his comments on the manuscript are also greatly appreciated.

\section{References}

Anonymous: Mallilaskelmat. Maaseutukeskusten Liitto (Association of Rural Advisory Centres), Helsinki, 1995, p. 52-59.

Anonymous: Finnish Milk Recording Results 1997, http://www.mloy.fi/mloy/my_html/tilastot.htm.

Anonymous: Finnish Animal Breeding Association,
1999, http://www.faba.fi/english/BLUP1.HTM.

DeLorenzo MA, Spreen TH, Bryan GR, Beede DK, Van Arendonk JAM: Optimization model: insemination, replacement, seasonal production and cash flow. J. Dairy Sci. 1992, 75, 885-896.

Houben EHP, Huirne RBH, Dijkhuizen AA, Kristensen AR: Optimal replacement of mastitic cows determined by a hierarchic Marcov process. J. Dairy Sci. 1994, 77, 2975-2993.

Houben EHP: Economic optimization of decisions with respect to dairy cow health management. Ph.D dissertation, Dept of Farm Management, Wageningen Agricultural University, Wageningen, 1995, pp.85-100.

Huirne RBM, Dijkhuizen AA, van Beek P, Renkema $J A$ : Dynamic programming to optimize treatment and replacement decisions. In: AA Dijkhuizen, RS Morris (eds): Animal Health Economics, Post Graduate Foundation in Veterinary Science, University of Sydney, Sydney, Australia, 1997, p. 8597.

Jalvingh $A W$ : The possible role of existing models in on-farm decision support in dairy cattle and swine production. Livestock Prod. Sci. 1992, 31, 351-365.

Jalvingh AW, Dijkhuizen AA, van Arendonk JAM: Optimizing the herd calving pattern by using linear programming and dynamic probabilistic simulation. J. Dairy Sci. 1994, 77, 1719.

Jalvingh,AW, van Arendonk JAM, Dijkhuizen AA: Dynamic probabilistic simulation of dairy herd management practices I. Model description and outcome of different seasonal calving patterns. Livest. Prod. Sci. 1993, 37, 107-131.

Jukola E, Hakkarainen J, Saloniemi H, Sankari S: Blood selenium, vitamin E, Vitamin A, and betacarotene concentrations and udder health, fertility treatments, and fertility. J. Dairy Sci. 1996, $79,838-845$.

Kay RD: Farm management. Planning, control and implementation. McGraw-Hill, Inc., New York, 1981, p.370.

Kristensen AR, Thysen I: Economic value of culling information in the presence and absence of a milk quota. Acta Agric Scand. 1991, 41, 129-135.

Mälkiä P: Personal communication, Association of Rural Advisory Centres, Helsinki, Finland, 1999.

McCullough DA: Effects of model specifications and exogenous variables on a stochastic dynamic insemination and replacement model for dairy cattle. MS Thesis, Department of Dairy Science. Gainesville, Univ. Florida 1992, p.168. 
McCullough DA, DeLorenzo MA: Evaluation of a stochastic dynamic replacement and insemination model for dairy cattle. J. Dairy Sci 1996a, 79, 50-61.

McCullough DA, DeLorenzo MA: Effects of price and management level on optimal replacement and insemination decisions. J. Dairy Sci. 1996b, 79, 242-253.

Rajala PJ, Gröhn YT: Disease occurrence and risk factors analysis in Finnish Ayrshire cows. Acta Vet. Scand. 1998a, 39, 1-13.

Rajala PJ, Gröhn YT: Effects of dystocia, retained placenta and metritis on milk yield in Finnish Ayrshire cows. J. Dairy Sci. 1998b, 81, 31723181.

Rajala-Schultz PJ, Gröhn YT: Culling of dairy cows. Part I. Effects of diseases on culling in Finnish Ayrshire cows. Prev. Vet. Med. 1999, 41, 195208.

Rajala-Schultz PJ, Gröhn YT, Allore HG: Optimizing breeding decisions for Finnish dairy herds. Acta vet. scand. 2000, 41, 213-226.

Taponen J: Personal communication, University of Helsinki, Faculty of Veterinary Medicine, Helsinki, Finland, 1999.

Van Arendonk JAM: Studies on the replacement policies in dairy cattle. II. Optimal policy and influence of changes in production and prices. Livest. Prod. Sci. 1985, 13, 101-120.

Van Arendonk JAM: Studies on the replacement policies in dairy cattle. IV. Influence of seasonal variation performance and prices. Livest. Prod. Sci. 1986, 14, 15-28.

Van Arendonk JAM, Dijkhuizen AA: Studies on the replacement policies in dairy cattle III. Influence of variation in reproduction and production. $\mathrm{Li}$ vest. Prod. Sci. 1985, 13, 333-349.

Winston WL: Operations Research. Applications and Algorithms. $3^{\text {rd }}$ ed. Belmont, California, Duxbury Pres. 1994, p.1318.

\section{Sammanfatting \\ Optimering av rekryterinsbeslut in finska mjölk- besättningar.}

Meningen med denna studie var att bestämma strukturen i en 'optimal besättning', gällande kalvningsmönster, besättningens medellivslängd och kalvingsintervall samt att evaluera hur känslig denna optimala lösning var för förändringar $i$ inputpriser, som reflekterade situationen i Finland år 1998. Studien utnyttjade en optimeringsmodell, utvecklad som beslutstöd för inseminering och rekrytering av mjölkkor, med finska inputvärden. Syftet med den dynamiska programmeringsmodellen var att maximera det väntade rådande nettovärdet av existerande och rekryteringskor över en bestämd beslutshorisont.

I den optimala lösningen var medelnettoinkomst per ko högst i december och lägst i juli, p.g.a. årstidsberoende prissättning av mjölk. Gällande det väntade rådande nettovärdet av kontant inkomst från en rekryterad kviga, var den bästa tiden för hennes kalvning i september. I den optimala lösningen var besättningens medellivslängd efter första kalvning 48.2 månader, vilket motsvarar ungefär 4 hela laktationer, och medeltalet för kalvningsintervallet var 363 dagar. Dock syntes en tydlig variation mellan årstider i kalvningsintervall (intervallet var längst på våren och under tidig sommar), som kan förklaras av en strävan till flera kalvningar på hösten. Detta, i sin tur, berodde på en högre produktion samt årstidsberoende prissättning av mjölk. I den optimala lösningen var den totala rekryteringsprocenten 26 , den högsta frekvensen av frivillig utmönstring sågs $\mathrm{i}$ slutet av året och de flesta kalvningarna på hösten. Månatliga säsongsmönster $\mathrm{i}$ kalvnings- och rekryteringsfrekvenser och variation i kalvningsintervallens längd eller besättningenslivslängd påverkades inte betydelsefullt av förändringar i kalv-, slaktkropps- eller foderpriser. När priset på rekryterinskvigor minskade var besättningens medellivslängd kortare och rekryterinsprocenten högre. När priset ökade var effekten den motsatta.

(Received May 25, 1999; accepted February 28, 2000).

Reprints may be obtained from: P.J. Rajala-Schultz, Department of Veterinary Preventive Medicine, College of Veterinary Medicine, The Ohio State University, 1900 Coffey Road, Columbus OH 43210, USA. E-mail: rajalaschultz.1@osu.edu, tel: 614-292-1206, fax: 614-292-4142. 